\title{
The role of museum studies in the development of the twenty-first century National Museum of Iceland
}

\author{
MARgRÉT HALLgRÍMSDótTIR
}

More than 150 years have passed since the National Museum of Iceland was founded. That is not a long time in the context of Iceland's history, yet several generations of Icelanders and museum workers have now grown up and developed with the Museum, its history bound up with the development of Icelandic society. A period of a century and a half has yielded invaluable experience and knowledge within an institution that is constantly undertaking new challenges.

At the beginning of this century the University of Iceland began teaching archaeology. In 2003, a partnership agreement was signed between the Museum and the University. In recent years, collaboration has increased in many fields e.g. in publications, exhibitions and teaching. Applied Studies in Culture and Communication have been taught at the University since 2006 and Museum Studies since 2009. Museum Studies in particular has influenced the development of museum practice by questioning the role of museums in a new era and by inspiring museum professionals. This may be said to underline how much the work of Icelandic museums has changed, and certainly advanced, since it has never been as varied as now.

As a result, the National Museum's activities have become more diverse in recent years and more open than they were, in compliance with the new demands in a new century. This applies equally to management methods, which include an increased emphasis on collaboration with other bodies and the dissemination of information as well as the quality of the professional field.

February 24, 1863 marks the beginning of the Museum's long journey, and that serves to remind us how long it has been since scholars and museum pioneers learned to value and preserve the cultural heritage. Sigurður Guðmundsson (1833-74), known as "the Painter," was an influential contributor to that discourse, and played a key role in the founding of the Antiquarian Collection, as the Museum was originally called. That event may be viewed in the broader European context of the time, when ideas about nations and nation-states were shaping views on the role of museums and galleries. In nineteenth-century Europe urban development and growing prosperity provided fertile soil for new ideas. Iceland had missed out on the industrial revolution, but by the nineteenth century towns and villages were growing, and in Reykjavík a bourgeois class was emerging. The purpose of museums in the nineteenth century was as much to foster cultural advances in society as to conserve heritage objects and art (Prösler 1996:31-32; Hafsteinsson 2015:7; Hallgrímsdóttir 2016). Icelanders were campaigning for self-determina- 
tion after centuries of Danish rule, and ideas from Europe along with rising nationalism contributed to patriotic notions of what the Icelandic nation might become.

The National Museum has passed many milestones since the realisation of the vision of Sigurður the Painter at a time when Icelanders were working towards independence. Sigurður's influence is explored in a recent book (Gunnell \& Aspelund 2017) which indicates that he and his allies envisioned museums growing up all over Iceland. That early step in that direction is seen in the first Antiquities Conservation Act of 1907, when Matthías Pórðarson was Director of the Museum. His successors Kristján Eldjárn and Pór Magnússon were also supportive of the development of local museums as well as the National Museum in general.

As a public institution, and a forum with a societal role, the Museum has been under constant re-evaluation since its foundation, not least since the beginning of the twentyfirst century, when the National Museum was rethought and remade from first principles for a new century with new expectations and challenges, while reflecting the Museum's long history and values.

At the start of this century, the museum building was closed for renovation, to reopen with a new permanent exhibition. That provided the opportunity for a new vision for the Museum. Organisational changes were made, and the Museum's role at the national level was redefined to take account of changing times. It has been a huge challenge to deal with new ideas in a different context in society combining secure preservation of heritage objects, diverse research and communication, all of which would take into account a new vision for the National Museum in changing times. The enactment in 2001 of new National
Heritage and Museums Acts marked a 141 turning-point, establishing in law the role of the National Museum as Iceland's principal museum in the field of cultural heritage.

The reopening of the National Museum in 2004 after refurbishment, with its new permanent exhibition, The Making of a Nation: Heritage and History in Iceland, marked a milestone that is an important foundation for exhibitions, research, discussions and communication in the Museum, based on research and work with the collection (HooperGreenhill 1992). Working conditions at the Museum were dramatically improved by the refurbishment and reorganisation, establishing new standards in museum practice in Iceland along with policy-making in the field. An important milestone has also recently been reached by establishing high-quality secure storage for part of the collections, thus ensuring better access for research and learning.

In 2006 the National Museum of Iceland received a special commendation from the European Museum Forum, which was an important encouragement. Through cultural events and activities of various kinds, addressing current and sometimes difficult issues, such as those concerning inequity of any kind, environmental issues and socially important topics that need to be discussed, the Museum seeks to reach out and bring more people into the forum that the Museum aims to be, inspiring new ideas and understandings of the nation's culture in past and present.

Collaboration has been a guiding principle of the National Museum's work. Over the years the National Museum has systematically cultivated its links with local heritage museums as close collaborators, and in the mid-twentieth century many local heritage museums were founded in the regions, and systematic efforts were made to save objects 
142 from the old rural society that was rapidly vanishing. Many such museums were housed in historic buildings owned by the National Museum, as encouraged by the legislation of the time (Hallgrímsdóttir 2016). Architectural conservation and museum work has thus gone hand-in-hand. The history of local museums is traced in a recent book published by the University of Iceland Research Centre in Museum Studies in collaboration with the National Museum (Hafsteinsson 2015). A policy has been developed for the practice of the heritage museums, which has contributed to developments in the field. The emphasis has been on long-term thinking, authenticity and quality in these smaller museums.

A vital role is also played by collaboration with various institutions in the cultural and educational sectors - especially with other bodies in the field of cultural heritage in Iceland and abroad. Collaboration with the University plays a growing role. Under the new National Museum of Iceland Act of 2013, the Museum was defined as a university institution in formal collaboration with the University of Iceland. The relationship between the two bodies was cemented through new objectives for joint research, knowledge creation and dissemination of knowledge.

Today the Museum relies on an interdisciplinary approach, in which Museum Studies play an important role in the institution's development - with emphasis on finding new ways to inspire and influence society and its people. Cooperation between the academic world and the Museum highlights the importance of a constant search for new methods and approaches - also in the context of safeguarding cultural heritage through broadranging collaboration between scholarship, public institutions, and not the least the people of the country.
The Museum is now a much-visited public institution, the principal museum of Icelandic cultural heritage, under whose aegis cultural activities flourish in local museums all around the country; a public body which provides expert conservation and study of Iceland's heritage, in collaboration with the University, other museums and cultural institutions.

Now, a little more than 150 years after its foundation, the National Museum aims to be a creative workplace in constant development, where the focus is on conservation and acquiring and disseminating new knowledge through inspiration and experience, leading to new ideas benefiting the local society in a global context. It has been pointed out that if development of public institutions is built on knowledge and experience, it reduces the chance of declining professionalism, while also helping to prevent "history deficit." (Fergusson 2015:31-32; Hooper-Greenhill 1992). Faced with new challenges, municipalities and governments in general increasingly interpret culture in terms of the demands of tourism and expect museums to shape their work accordingly. As well as devoting their work primarily to educational and cultural presentations, museums have become public spaces where the visitor plays a growing role (Aalst \& Boogaarts 2002:196).

The National Museum's collections comprise historical resources of increasing value in the quest for understanding the continuous narrative of past and present. The ideological principles of the National Museum's practice have evolved over the years since 1863: from national to international, from a dream of self-determination to a sense of shared responsibility transcending borders and time. This is in keeping with UNESCO's principle that one of the objectives of museum practice is to nurture one's own culture in the 
international context - the understanding of the importance of diversity, and the ability to place oneself in other people's shoes, whether in a narrow or broad context. It is also consistent with the findings of studies which explored the role of national museums in a period of cultural diversity and increased mobility, concluding that the museums play a new and vital role grounded in broadmindedness and humanitarian principles (Hooper-Greenhill 1992).

Like other museums, the National Museum of Iceland constantly aims to be a forum for debate and reflection, a meeting-place for people and ideas. The development of the museum work will go hand in hand with the museology and Museum Studies sparking new ideas and approaches, pushing the museum forward. With research and influence from academia, the Museum will continue to evolve, along with other essential agencies of culture and education with the aim to benefit society. The deep well of cultural heritage and memory will continue to contribute new understandings and ideas to Icelandic society, with knowledge leading to sustainable museum development. Museum Studies play and will continue to play an important role in that journey by encouraging the Museum to keep up with a changing world.

\section{LITERATURE}

van Aalst, Irina \& Ines Boogaarts 2002. “From museum to mass entertainment. The evolution of the role of museums in cities." European Urban and Regional Studies 9:3, 195-209.

Ferguson, Niall 2015. Kissinger 1923-1968: The Idealist. Volume 1. New York: Penguin Press.
Friðriksson, Guðjón 1991-1993. Saga Jónasar Jónssonar frá Hriflu I-III. Reykjavík: Iðunn.

Gunnell, Terry \& Karl Aspelund (eds.) 2017. Málarinn og menningarsköpun. Sigurður Guðmundsson og Kvöldfélagið 1858-1874. Reykjavík: Opna og pjóðminjasafn Íslands.

Hafsteinsson, Sigurjón Baldur (ed.) 2015. Byggðasöfn á Íslandi. Reykjavík: Rannsóknasetur í safnafræðum við Háskóla Îslands.

Hafsteinsson, Sigurjón Baldur \& Edda Björnsdóttir 2017. "Sigurður Guðmundsson og stofnun Forngripasafnsins.” In Karl Aspelund \& Terry Gunnell (eds.) Málarinn og menningarsköpun. Sigurður Guðmundsson og kvöldfélagið 1758-1874. Reykjavík: Opna og Pjóðminjasafn Íslands, 435-457.

Hallgrímsdóttir, Margrét 2016a. Pjóðminjar. Rit Pjóðminjasafns Íslands 42. Reykjavík: pjóðminjasafn Íslands og Crymogea.

Hooper-Greenhill, Eilean 1992. Museums and the Shaping of Knowledge. London \& New York: Routledge.

Pétursson, Hannes 1964. Steingrímur Thorsteinsson. Lif hans og list. Reykjavík: Bókaútgáfa Menningarsjóðs.

Prösler, Martin 1996. "Museums and globalization.” In Sharon McDonald \& Gordon Fyfe (eds.) Theorizing Museums. Representing Identity and Diversity in a Changing World. Oxford: Blackwell Publishing, 21-44.

\section{Margrét Hallgrímsdóttir, Director General,} margret@thjodminjasafn.is

National Museum of Iceland

Suðurgata 41

I-101 Reykjavík, Iceland

http://www.thjodminjasafn.is/ 